\title{
Species of the nematode genus Amidostomum Railliet and Henry, 1909 in aquatic birds in the Netherlands
}

\author{
F. H. M. BORGSTEEDE ${ }^{1}$, K. M. KAVETSKA², P. E. F. ZOUN ${ }^{3}$
}

\begin{abstract}
${ }^{1}$ Animal Sciences Group, Division Infectious Diseases, P.O. Box 65, 8200 AB Lelystad, the Netherlands, E-mail: fred.borgsteede@wur.nl; ${ }^{2}$ Division of Zoology, Faculty of Biotechnology and Animal Husbandry, Agricultural University, 20 Doktora Judyma Street, 71-450 Szczecin, Poland; ${ }^{3}$ Central Institute for Animal Disease Control (CIDC), P.O. Box 2004, 8203 AA Lelystad, the Netherlands
\end{abstract}

\begin{abstract}
Summary
The presence of gizzard worms belonging to the genus Amidostomum was studied in birds in the Netherlands during the period 1975 - 2003. Amidostomum acutum was found in Anatidae: Anas acuta, A. clypeata, A. crecca, A. penelope, A. platyrynchos, A. strepera, Aythya ferina, Ay. fuligula, Ay. marila, Bucephala clangula, Melanitta fusca, M. nigra, Tadorna tadorna, Somateria mollissima and Recurvirostra avocetta. No Amidostomum species were found in the following three species of Mergini: Mergus albellus, M. merganser and M. serrator. Amidostomum anseris was seen in Anser albifrons, A. fabalis, Branta bernicla and Branta leucopsis. Amidostomum cygni was detected in Cygnus bewickii and Cygnus olor, while Amidostomum fulicae was found in Fulica atra. The prevalence is only given for bird species where ten or more individuals had been investigated: Anas platyrhynchos $(\mathrm{n}=14)$ : $21.4 \%$; Melanitta nigra $(\mathrm{n}=12): 91.7 \%$; Somateria mollissima $(\mathrm{n}$ = 117): $100 \%$; Anser albifrons $(\mathrm{n}=11): 100 \%$ and Cygnus olor $(\mathrm{n}=10)$ : $60 \%$. Based on the present results, much more attention should be paid to the systematics, the epidemiological pattern and the pathogenicity of worms of this genus.
\end{abstract}

Key words: Amidostomum; birds; gizzard; the Netherlands

\section{Introduction}

It is surprising that in the Netherlands, a country with a very rich bird life of more than 300 species, relatively little is known about their helminth fauna. Van den Broek and Jansen Jr. (1964) and Van den Broek and Jansen (1971) mention the helminths of 54 bird species, of which 32 birds are typical water birds. For each bird species, they give only a few helminths and in almost half of the cases only one. The helminths of some birds, or group of birds, have been studied more extensively, such as the oystercatcher (Haematopus ostralegus) (Borgsteede et al., 1988), Passeri- formes (Borgsteede et al., 2000), birds of prey (Borgsteede et al., 2003) and the common eider (Borgsteede et al., 2005).

Recently much attention has been paid to the gizzard worm Amidostomum acutum in the common eider (Somateria mollissima). According to Borgsteede (2005), this nematode contributed - in combination with shortage of food - to mass mortality among adult eiders in the winter 2001/ 2002. Although the pathogenic role of $A$. acutum has hardly been described in the literature, another species of the genus, A. anseris, is a well known pathogenic gizzard worm in geese (Cram, 1926; Herman \& Wehr, 1954; Herman et al., 1955; Knudsen, 1966; Tuggle \& Crites, 1984). Vetési et al. (1976) did experimental studies with $A$. anseris in goslings, ducklings and chickens to demonstrate the histopathological changes.

Surveys of parasites in the gizzard of birds, particularly water birds, frequently mention the presence of an Amidostomum species in Europe (Palm, 1965; Orlandi \& Colombani, 1974; Macko, 1978; Ryšavý et al., 1982; Birová \& Macko, 1984; Macko \& Birová, 1985; Okulewicz, 1997; Straková, 1999; Betlejewska \& Kalisińska, 2001; Straková, 2001; Kavetska et al., 2004) and the US/Canada (Clark et al., 1958; Bishop \& Threlfall, 1974; Tuggle \& Crites, 1984; McLaughlin \& McGurk, 1987).

The interest in $A$. acutum has encouraged us to see how this species is spread among water birds in the Netherlands and which other species occur apart from A. acutum. Therefore, this study, based on material collected over a period of more than 25 years, describes the presence of species of the genus Amidostomum in birds in the Netherlands.

\section{Materials and Methods}

Investigated birds

In 1975, the Dutch Working Group on Bird Mortality started its work. Dead birds were collected by volunteers and 
sent to the Central Veterinary Institute. They were investigated by a specialist pathologist in bird diseases (the late Dr. Th. Smit) for the cause of death. He distributed the material from the birds among virologists, bacteriologists, toxicologists and a parasitologist (F.B.). Apart from the birds which were suspected of parasitism being the cause of death, it was a good opportunity to collect and study whole gastrointestinal tracts or parts thereof from birds that had died from other causes. The first author received more than 1700 whole intestinal tracts or parts of it from 149 bird species of which 71 birds which can be associated with water (Gaviidae, Podicipidae, Procellariidae, Sulidae, Phalacrocoracidae, Ardeidae, Ciconiidae, Plataleidae, Anatidae, Rallidae, Haematopodidae, Charadriidae, Scolopacidae, Recurvirostridae, Stercorariidae, Laridae and Alcidae) in the period during which the Working Group was active $(1975-1990)$ and thereafter till 2004.

\section{Collection of parasites}

The gizzards were opened and the contents washed with tap water. The washings were collected in a bucket. Thereafter, the koilin layer of the gizzard was removed and the gizzard was washed again and scraped off with a blunt knife. All material was collected in the same bucket. The koilin layer was examined under a stereomicroscope (magn. 6 $\mathrm{x})$ for the presence of worms. The contents of the bucket were poured over a sieve (screen mesh $0.074 \mathrm{~mm}$ ). The material on the sieve was suspended in buffered $4 \%$ formaldehyde solution and stored for later examination. All collected worms were identified at the species level (Czaplinski, 1962; Baruš et al., 1978; Ryšavý et al., 1982).

\section{Results}

Table 1 lists the bird species in which an Amidostomum species was found. Within the Anatidae, results from 25 bird species were available, of which 22 were positive for Amidostomum. No Amidostomum species were seen in the fish eating ducks: Mergus albellus $(\mathrm{n}=21), M$. merganser $(\mathrm{n}=1)$ and $M$. serrator $(\mathrm{n}=26)$. In the ducks, A. acutum was the only species, in geese $A$. anseris and in swans $A$. cygni.

Because the number of birds per species is generally low, it is not reliable to give a percentage of prevalence. If we regard a number of birds per species of ten or more as a minimum for a realistic assessment of the prevalence, then we see the following prevalences: Anas platyrhynchos $(\mathrm{n}=$ 14) $21.4 \%$; Melanitta nigra $(\mathrm{n}=12) 91.7 \%$; Somateria mollissima $(\mathrm{n}=117) 100 \%$; Anser albifrons $(\mathrm{n}=11) 100$ $\%$ and Cygnus olor $(\mathrm{n}=10): 60 \%$.

Outside the Anatidae, we found A. fulicae in Fulica atra and $A$. acutum in Recurvirostra avocetta.

\section{Discussion}

The study clearly shows that the genus Amidostomum is well represented in the Anatidae in the Netherlands. This is in agreement with others who studied helminths of water

Table 1. List of the bird species in which an Amidostomum species was found

\begin{tabular}{|c|c|c|c|c|c|c|c|c|}
\hline Family & Subfamily & Tribe & Species & $\begin{array}{c}\text { No. } \\
\text { gizzards }\end{array}$ & A. acutum & A. anseris & A. cygni & A. fulicae \\
\hline \multirow[t]{6}{*}{ Anatidae } & Anatinae & Anatini & Anas platyrhynchos & 14 & 3 & & & \\
\hline & & & Anas crecca & 3 & 2 & & & \\
\hline & & & Anas penelope & 5 & 1 & & & \\
\hline & & & Anas strepera & 1 & 1 & & & \\
\hline & & & Anas acuta & 2 & 1 & & & \\
\hline & & & Anas clypeata & 1 & 1 & & & \\
\hline \multirow[t]{4}{*}{ Anatidae } & Anatinae & Aythyini & Aythya marila & 8 & 7 & & & \\
\hline & & & Aythya fuligula & 4 & 3 & & & \\
\hline & & & Aythya ferina & 5 & 2 & & & \\
\hline & & & Bucephala clangula & 3 & 1 & & & \\
\hline \multirow[t]{6}{*}{ Anatidae } & Anatinae & Mergini & Melanitta fusca & 2 & 2 & & & \\
\hline & & & Melanitta nigra & 12 & 11 & & & \\
\hline & & & Mergus serrator & 26 & & & & \\
\hline & & & Mergus merganser & 1 & & & & \\
\hline & & & Mergus albellus & 21 & & & & \\
\hline & & & Somateria mollissima & 117 & 117 & & & \\
\hline Anatidae & Tadornidae & & Tadorna tadorna & 9 & 4 & & & \\
\hline \multirow[t]{6}{*}{ Anatidae } & Anserinae & & Anser albifrons & 11 & & 11 & & \\
\hline & & & Anser fabalis & 1 & & 1 & & \\
\hline & & & Branta bernicla & 6 & & 3 & & \\
\hline & & & Branta leucopsis & 1 & & 1 & & \\
\hline & & & Cygnus olor & 10 & & & 6 & \\
\hline & & & Cygnus bewickii & 1 & & & 1 & \\
\hline Rallidae & & & Fulica atra & 6 & & & & 2 \\
\hline Recurvirostridae & & & Recurvirostra avocetta & 6 & 4 & & & \\
\hline
\end{tabular}


fowl in Europe. In Czechoslovakia, A. acutum was observed in Anas platyrhynchos, A. querquedula, A. crecca, A. penelope, A. clypeata, A. acuta, Aythya nyroca, Ay. fuligula, Ay. ferina and Anser anser. Amidostomum anseris was found in Anser anser and A. fabalis. In Anser fabalis, also Amidostomum spatulatum was present (Macko, 1978; Birová \& Macko, 1984; Macko \& Birová, 1985; Straková, 1999; Straková, 2001). The finding of A. acutum in Anser anser is remarkable, as this species is mainly found in Anatini. Conversely, the presence of a typical 'geese' Amidostomum in Anatini is repeatedly mentioned. Christiansen (1948) and Persson et al. (1974) mention the presence of A. anseris in the common eider. This is probably an incorrect identification, because all others who have studied the parasite fauna of common eiders found exclusively $A$. acutum. A survey of stomach worms of wild ducks in Poland showed the presence of A. acutum in several Anatini, Aythyini and Mergini (Betlejewska \& Kalisińska, 2001). The results of these authors confirm our finding, that Amidostomum was absent in birds of the genus Mergus. It is likely that this is related to their source of food (mainly fish). As far as the authors know, there is no record of Amidostomum species from ducks of the genus Mergus.

The life cycle of $A$. anseris has been studied by many authors (Enigk et al., 1975; Stradowski, 1974, 1975, 1977). Leiby and Olsen (1965) investigated the life cycle of $A$. raillieti and A. skrjabini (according to Czaplinski, 1962, resp. A. fulicae and A. acutum). The life cycle of Amidostomum species is a direct life cycle type, in which third stage larvae hatch from the egg and are ingested by the final host. It is not known if infection of birds can take place by skin penetration of the infective larvae as described for A. anseris (Enigk \& Dey-Hazra, 1968). However, little is known about the epidemiological pattern in nature, or where the birds pick up their infection. Typically, it is unknown where 'sea' ducks, such as Somateria mollissima and Melanitta nigra become infected, whether it is during their period on land and infective larvae are present in fresh water ponds or if infection is also possible in brackish water or salt water.

The pathogenic role of members of the genus is well described for $A$. anseris in geese (Cram, 1926; Herman \& Wehr, 1954; Herman et al., 1955; Knudsen, 1966; Tuggle $\&$ Crites, 1984). Borgsteede (2005) suggested that in periods of food shortage, infections with $A$. acutum in common eiders may be fatal. There are hardly any other records of the pathogenicity of A. acutum. Persson et al. (1974) described some severe cases of amidostomosis in the common eider and Clark et al. (1958) reported an epizootic among eiders, which they ascribe to an acanthocephalan infection, but they also mention that all six investigated ducks were infected with Amidostomum. The only record of possible pathogenicity of $A$. cygni can be found in the description of parasitism in a flock of mute swans in Scotland (Pennycott, 1998). One immature out of 14 swans, had a severe Amidostomum (probably A. cygni) infection. The koilin layer was soft, easily disrupted and discoloured black/brown. The pathogenicity of $A$. spatulatum,
A. fulicae and A. henryi has not been described.

Much can be said about the systematics of the genus Amidostomum. Czaplinski (1962) revised the genus and brought the number of species back to six: A. acutum, A. anseris, A. cygni, A. fulicae, A. henryi and A. spatulatum. Petrova (1987) subdivided the genus into two subgenere: Amidostomum and Amidostomoides. The main difference between the two generera is the presence of only one tooth in the buccal capsule in Amidostomoides. Lomakin (1993) made another revision. He promoted the subgenus Amidostomoides of Petrova (1987) to the genus Amidostomoides with 6 species: Amidostomoides acutum from Anseriformes: Anas acuta, A clypeata, A. formosa, A. platyrhynchos, A. poecilorhyncha, A. strepera, A. crecca, A. querquedula, Aythya ferina, Ay. fuligula, Netta rufina, Bucephala clangula, Clangula hiemalis, Somateria mollissima, Melanitta nigra, M. fusca and Anser albifrons; Ralliformes: Fulica atra; Charadriiformes: Himantopus himantopus; Galliformes: Tetrastes bonasia, Tetrao urogallus, Lagopus lagopus and L. mutus. Amidostomoides auriculatum in Anas crecca and A. querquedula. Amidostomoides henryi in Vanellus vanellus and Anas crecca. Amidostomoides monodon in Melanitta nigra, M. fusca, $M$. deglandii, Somateria mollissima, S. fischeri and S. spectabilis. Amidostomoides petrovi in Clangula hiemalis, Bucephala clangula, Somateria spectabilis, Aythya baeri, Ay. marila, Ay. nyroca, Ay. fuligula, Melanitta nigra, C. Gallinago and Recurvirostra avocetta. Finally, Amidostomoides tribonix in Tribonix ventralis.

Anderson (2000), in his book on the development and transmission of nematode parasites of vertebrates does not follow the systematics of Lomakin (1993). Although there are clearly anatomical differences within the species $\mathrm{A}$. acutum, it is questionable whether these are really species specific characteristics or host related differences. Although it is tempting to split Amidostomum acutum into different species according to the systematic divison of the ducks: Amidostomoides acutum mainly occurring in Anatini (dabbling ducks), Amidostomoides petrovi mainly in Aythyini (diving ducks) and Amidostomoides monodon mainly in Mergini ('sea' ducks), experimental infections in parasite free birds of the several species could clarify the situation. However, these experiments are almost impossible to carry out in practice. The answer could be found in a molecular biological analysis of the genome of the worms from different hosts and establish their relationship.

\section{Acknowledgements}

The comments of Dermot O'Brien and his corrections of the English text are greatly acknowledged.

\section{References}

ANDERSON, R. C. (2000): Nematode parasites of vertebrates. Their development and transmission. CABI Publishing, Wallingford, UK

Baruš, V., Sergeeva, T. P., Sonin, M. D., Ryzhikov, K. 
M. (1978): Helminths of fish-eating birds of the Palearctic region. I. Nematoda. USSR Academy of Sciences, Helminthological Laboratory. Czechoslovak Academy of Sciences, Institute of Parasitology. Moscow and Prague

BetlejewsKa, K. M., KAlisińsKA, E. (2001): Amidostomum acutum (Nematoda) in mallards Anas platyrhynchos L. of Northwest Poland. Animal Prod. Review, Appl. Sci. Rep. 57: Poultry Prod. Breed., XIII ${ }^{\text {th }}$ Int. Symp. of young poultry scientists, Cracow 2002: $69-75$

Bishop, C. A., THRELFALL, W. (1974): Helminth parasites of the common eider duck, Somateria mollissima (L.), in Newfoundland and Labrador. Proc. Helminthol. Soc. Wash., 41: 25 - 35

BirovÁ, V., MACKO, J. K. (1984): Helminths of Anas platyrhynchos L. before and after water system regulations on the East Slovakian lowland. Biológia (Bratislava). 39: 911 $-947$

Borgsteede, F. H. M. (1988): Helminth parasites of the digestive tract of the oystercatcher Haematopus ostralegus in the Wadden Sea, The Netherlands. Neth. J. Sea Res., 22: $171-174$

Borgsteede, F. H. M., OKulewicz, A., OKulewicz, J. (2000): A study of the helminth fauna of birds belonging to the Passeriformes in the Netherlands. Acta Parasitol., 45: $14-21$

Borgsteede F. H. M., OKulewicz, A., Zoun, P. E. F., OKuLEWICZ, J. (2003): The helminth fauna of birds of prey (Accipitriformes, Falconiformes, Strigiformes) in the Netherlands. Acta Parasitol., 48: 200 - 207

Borgsteede, F. H. M., OKulewitz, A., Zoun, P. E. F., OKULEWITZ, J. (2005): The gastrointestinal helminth fauna of the eider duck (Somateria mollissima L.) in the Netherlands. Helminthologia, 42: $83-87$

Borgsteede, F. H. M. (2005): The gizzard worm, Amidostomum acutum (Lundahl, 1848) Seurat, 1918 in common eiders (Somateria mollissima L.) in the Netherlands. Helminthologia, 42: 215 - 218

Christiansen, M. (1948): Epidemiagtigt sygdomsutbrud blandt ederfugle (Somateria mollissima L.) ved Bornholm, foraarsaget af dyriske Snyltere. Dansk Ornithol. Foren. Tidsskr., 42: $41-47$

Clark, G. M., O’Meara, D., Van Weelden, J. W. (1958): An epizootic among eider ducks involving an acanthocephalid worm. J. Wildlife Management, 22: 204 - 205

CRAM, E. B. (1926): A parasitic nematode as a cause of loss among domestic geese. North Amer. Vet., 7: 27 - 29

CZAPlinsKI, B. (1962): Nematodes and acanthocephalans of domestic and wild Anseriformes in Poland. I. Revision of the genus Amidostomum Railliet and Henry, 1909. Acta Parasitol. Pol., 10: 125 - 164

ENIGK, K., DEY-HAZRA, A., BATKE, J. (1975): Zur Epizootologie und Behandlung des Helminthenbefalles der Gans. Acta Parasitol. Pol., 23: 26 - 40, 373 - 379

ENIGK, K., DEY-HAZRA, A.. (1968): Die perkutane Infektion bei Amidostomum anseris (strongyloidea, Nematoda). Zschr. Parasitenk., 31: 155 - 165

Herman, C. M., WeHr, E. E. (1954): The occurrence of gizzard worms in Canada geese. J. Wildl. Managem., 18:
$509-513$

Herman, C. M., Steenis, J. H., Wehr, E. E. (1955): Causes of winter losses among Canada geese. Trans. N. Amer. Wildlife Conf., 20: $161-165$

KAVETSKa, K. M., KalisińsKa, E., Kornyushin, V. V., KuZMIN, Y. (2004): Stomach nematodes of wild ducks (subfamily Anatidae) from Northwestern Poland. Acta Parasitol., 49: 162 - 167

KNUDSEN, E. (1966): Amidostomiasis og acuariasis hos svømmefugle. Nord. Veterinaer-Med., 18: 38 - 43

LEIBY, P. D., OlsEN, O. W. (1965): Life history studies on nematodes of the genera Amidostomum (Strongyloidea) and Epomidiostomum (Trichostrongyloidea) occurring in the gizzards of waterfowl. Proc. Helminthol. Soc. Wash., 32: $32-49$

LOMAKIN, V. V. (1993): Revision of nematodes of the subfamily Amidostomatinae Travassos, 1919 (Amidostomatidae; Strongylida). Trudy Gelmint. Labor., 39: 92 - 122 MACKO, J. K. (1978): On the nematodes of Anas crecca L. in the spring seasons of 1954-1970. Zbornik Východoslov. Múzea v Košiciach 19AB: $61-65$

MACKO, J. K., BIROVÁ, V. (1985): On the natural distribution of foci of helminthoses of domestic ducks in Eastern Slovakia. Polnohospodárstvo, 31: $77-87$

McLaughlin, J. D., McGurK, B. P. (1987): An analysis of gizzard worm infections in fall migrant ducks at Delta, Manitoba, Canada. Canad. J. Zool., 65: 1470 - 1477

Okulewicz, A. (1997): Catalogue of the Polish parasite fauna - parasites of birds. Part IV, Vol. 2B. PtP, Warzawa

ORLANDI, M., COLOMBANI, B. (1974): Elmintiasi da nematodi dello stomaco ghiandolare e dello stomaco musculare in uccelli selvatici. Ann. della Fac. Medicin. Veterin. di Pisa, 27: $113-128$

PALM, V. (1965): Ein Beitrag zur helminthenfauna des Blesshuhns (Fulica atra L.) aus dem Raum von Potsdam. Acta Parasitol. Pol., 13: 425 - 444

PENNYCOTT, T. W. (1998): Lead poisoning and parasitism in a flock of mute swans (Cygnus olor) in Scotland. Vet. Rec., 142: 13 - 17

Persson, L., BorG, K., FÄLt, H. (1974): On the occurrence of endoparasites in eider ducks in Sweden. ViltrevyStockholm, 9: $1-24$

Petrova, K. (1987): Species composition and morphology of the genus Amidostomum Railliet et Henry 1909 (Strongylata: Amidostomatidae) in Bulgaria. Khelmintologiya, 24: $53-72$

RYŠAVÝ, B., GROSCHAFT, J., BARUŠ, V., DVOŘÁKOVÁ, L. (1982): Helminths of water poultry. Czechoslovak Academy of Sciences, Prague

STRADOWSKI, M. (1974): Development of eggs and larvae of Amidostomum anseris (Zeder, 1800) under laboratory conditions. Acta Parasitol. Pol., 22: 415 - 422

STRADOWSKI, M. (1975): Wintering of Amidostomum anseris (Zeder, 1800) eggs under climatic conditions in Central Poland. Acta Parasitol. Pol., 23: 373 - 379

STRADOWSKI, M. (1977): Duration of prepatent, patent and postpatent periods of the Amidostomum anseris (Zeder, 1800) infection in domestic geese. Acta Parasitol. Pol., 24: 
$249-258$

STRAKOVÁ, S. (1999): Gizzard worms (Strongylata: Amidostomatidae) in wild gesse in southern Moravia (Czech Republic). Folia Venatoria, 28 - 29: 143 - 154

STRAKOVÁ, S. (2001): Survey of parasites in game water birds in the surroundings of Novomlynske's reservoirs (southern Moravia). Myslivecké listy, 2: 15 - 21

Tuggle, B. N., CRITES, J. L. (1984): The prevalence and pathogenicity of gizzard nematodes of the genus Amidostomum and Epomidiostomum (Trichostrongylidae) in the lesser snow goose (Chen caerulescens caerulescens). Ca-

RECEIVED August 8, 2005 nad. J. Zool., 62: $1849-1852$

VAN DEN BRoEK, E., JANSEN JR, J. (1964): Parasites of animals in the Netherlands. Supplement I: Parasites of wild birds. Ardea, 52: $111-116$

VAn Den BRoek, E., Jansen, J. (1971): Parasites of animals in the Netherlands. Supplement V: Endoparasites of wild birds. Ardea, 59: 28 - 33

Vetési, F., Phuc, D.V., VARGA, I. (1976): Histopathological changes in the gizzard of goslings, ducklings and chickens experimentally infected with Amidostomum anseris. Acta Vet. Acad. Sci. Hung., 26: 113 - 128

ACCEPTED FEBRUARY 21, 2006 